\title{
PENTINGNYA MANAJEMEN KEUANGAN KELUARGA PADA IBU PKK KELURAHAN PONDOK BENDA GUNA MEMINIMALISIR PENGELUARAN DAN ANIMO MENABUNG DITENGAH PANDEMI COVID-19
}

\author{
Jamaludin*, Bulan Oktrima, Shelby Virby, Gina Fauziah, Sairin \\ Dosen Prodi Manajemen Fakultas Ekonomi Universitas Pamulang \\ Email : dosen01020@unpam.ac.id, dosen00790@unpam.ac.id, \\ dosen01364@unpam.ac.id,ginnafauziah@gmail.com, Sairin.irin@yahoo.co.id
}

\begin{abstract}
ABSTRAK
Pengabdian Kepada Masyarakat (PKM) merupakan salah satu darma dari tri dharma perguruan tinggi, maka dari itu melakukan PKM merupakan suatu keharusan bagi Dosen minimal 1 kali dalam satu semester. Adapun tujuan dari kegiatan Pengabdian Kepada Masyarakat adalah untuk mengetahui manajemen keuangan keluarga dengan baik dan benar ditengah pandemic Covid-19, untuk mengetahui cara meminimalisir pengeluaran keuangan keluarga secara efektif ditengah pandemic Covid-19, dan untuk menumbuhkan minat menabung bagi Ibu PKK ditengah pandemic Covid-19.

Supaya PKM ini tepat sasaran, maka perlu diperhatikan metode pelaksanaan PKM. Adapun metode pelaksanaan PKM ini adalah dengan cara: Dalam melaksanakan kegiatan PKM ini digunakan beberapa metode yaitu: 1. Metode Ceramah / Presentasi, Metode ceramah / presentasi dipilih untuk memberikan penjelasan mengenai: a. Memberikan pengetahuan terkait dengan memanajemen keuangan keluarga yang baik dan benar ditengah pandemic covid-19; b. Memberikan pengetahuan terkait dengan cara meminimalisir pengeluaragan keuangan keluarga secara efektif ditengah pandemic covid19; c. Memberikan pengetahuan terkait dengan cara menumbuhkan minat menabung bagi Ibu PKK ditengah pandemic covid-19. 2. Metode Tanya Jawab. Metode Tanya jawab sangat penting bagi para peserta. Metode ini memungkinkan para ibu PKK menggali pengetahuan sebanyak-banyaknya tentang Pentingnya Manajemen Keuangan Keluarga Pada Ibu Pkk Kelurahan Pondok Benda Guna Meminimalisir Pengeluaran Dan Animo Menabung Ditengah Pandemi Covid-19. 3. Sharing Session. Tentang Pentingnya Manajemen Keuangan Keluarga Pada Ibu Pkk Kelurahan Pondok Benda Guna Meminimalisir Pengeluaran Dan Animo Menabung Ditengah Pandemi Covid-19. Sharing session ini diberikan kepada para peserta guna mendorong membimbing Ibu PKK.

Adapun hasil dari PKM ini nantinya akan dievaluasi berdasarkan taraf penyelesaian materi pelatihan, dan selanjutnya tim kegiatan PKM akan melakukan evaluasi tersebut dengan mengamati dan memeriksa metode pelaksanaan yang sudah dirancang dan yang telah diberikan kepada Ibu PKK sebagai peserta.
\end{abstract}

Keywords: Manajemen Keuangan, Tabungan, dan Covid-19

\begin{abstract}
ABSTRAC
Community Service (PKM) is one of the principles of the Tri Dharma of Higher Education, therefore conducting PKM is a must for lecturers at least once a semester. The purpose of Community Service activities is to know family financial management properly and correctly in the midst of the Covid-19 pandemic, to find out how to effectively
\end{abstract}


minimize family financial expenses amid the Covid-19 pandemic, and to foster interest in saving for PKK mothers amid the Covid-pandemic. 19.

In order for this PKM to be right on target, it is necessary to pay attention to the method of implementing PKM. The method of implementing this PKM is by: In carrying out this PKM activity several methods are used, namely: 1. Lecture / Presentation Method, The lecture / presentation method is chosen to provide an explanation of: a. Providing knowledge related to good and correct family financial management amid the Covid-19 pandemic; b. Providing knowledge related to how to effectively minimize family financial expenses amid the Covid-19 pandemic; c. Providing knowledge related to how to foster interest in saving for PKK mothers in the midst of the Covid-19 pandemic. 2. Question and Answer Method. The question and answer method is very important for the participants. This method allows PKK mothers to gain as much knowledge as possible about the Importance of Family Financial Management at Pkk Pondok Benda Village to Minimize Expenditures and Saving Interest Amid the Covid-19 Pandemic. 3. Sharing Session. Concerning the Importance of Family Financial Management in Pkk Pondok Benda Village in order to Minimize Expenditures and Saving Interest Amid the Covid-19 Pandemic. This sharing session was given to the participants to encourage mentoring PKK mothers.

The results of this PKM will later be evaluated based on the level of completion of the training material, and then the PKM activity team will carry out the evaluation by observing and examining the implementation methods that have been designed and that have been given to PKK mothers as participants.

Keywords: Financial Management, Savings, and Covid-19

\section{PENDAHULUAN}

Pada awal 2020, dunia dikejutkan dengan mewabahnya pneumonia baru yang bermula dari Wuhan, Provinsi Hubei yang kemudian menyebar sangat cepat ke lebih dari 190 negara. Wabah ini diberi nama coronavirus disease 2019 (COVID-19), yang disebabkan oleh Severe Acute Respiratory Syndrome Coronavirus-2 (SARS-CoV-2). Sejak itulah semua kegiatan salah satunya perekonomian terhambat, dan bahkan berdampak pada kehidupan perekonomian keluarga, artinya bahwa dampak yang timbul akibat pandemic menyasar sampai padaa pengelolaan keuangan keluarga, dikarenakan sangat sulit mendapatkan uang selama pandemic, belum lagi sebagian masyarakat rela kehilangan pekerjaannya. Dengan demikian peran manajer keuangan keluarga dalam hal ini Ibu rumah tangga harus pintar dalam mengelola keuangan keluarganya.

Banyak orang beranggapan bahwa Manajemen keuangan keluarga merupakan salah satu bidang yang rumit. Sebenarnya manajemen keuangan keluarga tidaklah rumit seperti yang dibayangkan banyak orang, khususnya ibu-ibu yang sering di daulat sebagai manajer keuangan keluarga. Untuk menjadi manajer keuangan keluarga yang cerdas dan bijak, tidaklah harus menjadi seorang ahli keuangan.

Manajemen keuangan keluarga memang membutuhkan pengetahuan dan kearifan dalam menjalankannya. Kebanyakan orang yang merasa terintimidasi dengan masalah ini, malah mengabaikannya. Persoalaan ini harusnya menjadi prioritas keluarga karena banyak sekali masalah timbul karena kurang bijaknya manajer keuangan keluarga dalam mengelola dan mengatur keuangannya. Sebagai seorang manajer keuangan keluarga, ada beberapa aspek yang perlu ditangani yaitu: Membuat dan meninjau secara perisodik prioritas keuangan keluarga, Mengelola pendapatan yang terbatas secara bijakMenghitung kebutuhan proteksi serta menginvestasikan dana dalam bentuk investasi yang sesuai, Menentukan sebuah rencana pension, Mempersiapkan 
dana pendidikan untuk anak-anak, Belanja dengan bijak, Mengajarkan anak-anak mengenai keuangan.

Ini merupakan hal-hal dasar yang sebaiknya dipikirkan dan direncanakan oleh keluarga melalui seorang manajer keuangan keluarga, bisa ibu atau bapak atau keduanya. Keuangan keluarga pasti akan dihadapi dengan berbagai hambatan baik kecil maupun besar. Bisa jadi hambatan ini mengakibatkan krisis keuangan. Cobalah untuk merencanakan bagaimana keluar dari masalah dan dapat terus menjalani kehidupan keluarga secara sejahtera.

Tujuan keuangan keluarga harus dinyatakan dalam nilai yang terukur serta jangka waktu pencapaiannya. Misalkan, seseorang meneginginkan untuk dapat hidup berkecukupan di masa tua nanti. Itu merupakan tujuan tapi belum spesifik masih dibutuhkan suatu nilai yang dapat dituju dimasa depan, misalkan saja seseorang membutuhkan dana Rp.1 milyar untuk dapat hidup layak di masa tua nanti. Jadi tujuan keuangan yang benar adalah pensiun di usia 55 tahun dengan dana yang harus dimiliki adalah 1 milyar rupiah. Satu hal yang juga penting dalam menentukan tujuan keuangan keluarga adalah realistik. Jangan, menentukan tujuan keuangan yang tidak realistik dengan keadaan keuangan sekarang. Jadi hal ini bukanlah sebuah impian yang tidak mungkin dicapai seperti halnya kodok merindukan bulan. Tapi merupakan tujuan yang secara sadar dapat di capai melalui pelaksanaan yang berkesinambungan. Mengapa hal ini sangat penting, karena tujuan keuangan merupakan pondasi sebuah perencanaan keuangan keluarga. Menentukan tujuan keuangan diluar kemampuan malah akan menjadi bumerang dimasa depan. Hal ini dapat saja membuat orang tersebut malah tidak melakukan perencanaan sama sekali. Dengan demikian perlu dilakukan sebuah terobosan dalam memberikan pemahaman pada Ibu PKK. PKM inilah sebagai salah satu solusi akan pemahaman tersebut. Maka PKM ini mengangkat sebuah tema "PENTINGNYA MANAJEMEN

\section{KEUANGAN KELUARGA PADA IBU PKK KELURAHAN PONDOK BENDA GUNA MEMINIMALISIR PENGELUARAN DAN ANIMO MENABUNG DITENGAH PANDEMI COVID-19"}

\section{RUMUSAN MASALAH}

Dengan mempertimbangkan latar belakang yang telah dijelaskan diatas, Adapun rumusan masalah dalam PKM ini adalah:

1. Bagaimana Manajemen Keuangan yang baik dan benar ditengah pandemic covid-19 pada Ibu PKK Pondok Benda?

2. Bagaimana cara meminimalisir pengeluaran keuangan keluarga secara efektif ditengah pandemic Covid-19 pada Ibu PKK Pondok Benda?

3. Bagaimana menumbuhkan minat menabung bagi Ibu PKK ditengah pandemic Covid-19?

\section{TUJUAN PELAKSANAAN}

Adapun tujuan dari kegiatan Pengabdian Kepada Masyarakat adalah:

1. untuk mengetahui manajemen keuangan keluarga dengan baik dan benar ditengah pandemic Covid-19,

2. untuk mengetahui cara meminimalisir pengeluaran keuangan keluarga secara efektif ditengah pandemic Covid-19, dan

3. untuk mengetahui cara menumbuhkan minat menabung bagi Ibu PKK ditengah pandemic Covid-19

\section{TINJAUAN PUSTAKA}

\section{Manajemen Keuangan}

Menurut Hasibuan (2012:2) manajemen adalah ilmu dan seni mengatur proses pemanfaatan sumber daya manusia dan sumber lainnya secara efektif dan efisien untuk mencapai suatu tujuan tertentu. 
Sedangkan menurut Abdurrahmat Fatoni (2011:3) manajemen adalah proses kegiatan menggerakan sekelompok orang dan menggerakan fasilitas yang tersedia untuk mencapai tujuan tertentu.

Meskipun tugas dan tanggung jawab berbeda-beda pada setiap perusahaan, namun tugas pokok manajemen keuangan antara lain menyangkut keputusan tentang penanaman modal, pembagian kegiatan usaha, dan pembagian deviden pada berbagai perusahaan.

Jadi kesimpulannya bahwa manajemen keuangan adalah Dari pengertian ini dapat disimpulkan bahwa aktivitas manajemen keuangan berkaitan erat dengan pengelolaan keuangan perusahaan termasuk lembaga yang berhubungan erat dengan sumber pendanaan dan investasi perusahaan serta instrument keuangan.

\section{Fungsi Manajemen Keuangan}

Fungsi manajemen keuangan menurut Sutrisno (2017:5) terdiri dari tiga keputusan utama yang harus dilakukan oleh suatu perusahaan yaitu:

1. Keputusan Investasi

Keputusan investasi adalah masalah bagaimana seorang manajer keuangan harus mengalokasikan dana ke dalam bentuk-bentuk investasi yang akan dapat mendatangkan keuntungan dimasa yang akan datang. Bentuk, macam, dan komposisi dari investasi tersebut akan mempengaruhi dan menunjang tingkat keuntungan dimasa mendatang.

2. Keputusan Pendanaan

Keputusan ini sering disebut juga kebijakan struktur modal. Pada keputusan ini manajer keuangan dituntut untuk mempertimbangkan dan menganalisis kombinasi dari sumber-sumber dana yang ekonomis bagi perusahaan guna pembelanjaan kebutuhankebutuhan investasi serta kegiatan investasinya.

3. Keputusan Deviden

Deviden merupakan bagian keuntungan yang dibayar oleh perusahaan kepada para pemegang saham. Oleh karena itu deviden ini merupakan bagian dari penghasilan yang diharapkan oleh pemegang saham. keputusan ini merupakan keputusan manajemen keuangan untuk menentukan:

a. Besarnya presentase laba yang dibagikan kepada para pemegang saham dalam bentuk cash devidend.

b. Stabilitas deviden yang dibagikan

c. Deviden saham (stock devidend)

d. Pemecahan saham (stock split)

e. Penarikan kembali saham beredar yang semuanya ditunjukan untuk meningkatkan kemakmuran para pemegang saham.

4. Tabungan (saving)

Tabungan (saving) merupakan bagian pendapatan dari seseorang, sebuah perusahaan atau lembaga yang tidak dibelanjakan atau dikeluarka untuk konsumsi sekarang (Kabae, 2016). Tabungan biasanya disimpan dalam bentuk deposito pada bank, lembaga-lembaga keuangan, dan sebagainya, atau digunakan untuk mendapatkan aktiva-aktiva keuangan seperti saham, obligasi, dan lain-lain.

Dengan menangguhkan pengeluaran untuk konsumsi, penabung dapat meningkatkan pendapatan mereka di masa depan melalui dividen atau bunga.

Dalam analisis ekonomi makro, tabungan merupakan bagian dari pendapatan nasional yang tidak digunakan untuk konsumsi saat ini. Tabungan sangat penting dalam membiayai investasi fisik Menabung 
Loyalitas Kreativitas
Aldi Masyarakat Kreatif
P-ISSN 2722-2101, E-ISSN 2722-4201

Program Studi Ekonomi Manajemen Universitas Pamulang

Jurnal LOKABMAS Kreatif Vol. 01, No. 03, Hal. 112-123

Email:jurnalkreatif.manajemen@gmail.com berarti menyimpan sumber daya yang dapat digunakan untuk meningkatkan modal perusahaan, sehingga akan meningkatkan kapasitasnya untuk memproduksi lebih banyak barang

Tabungan berasal dari beberapa sumber (Kabae, 2016) sebagai berikut:

a. Tabungan Pemerintah

Tabungan pemerintah hampir seluruhnya berasal dari kelebihankelebihan penerimaan pemerintah secara keseluruhan atas pengeluaran konsumsi pemerintah.Beberapa penelitian menunjukkan bahwa tabungan pemerintah tidaklah terlalu besar. Hanya ada sedikit kasus di mana tabungan pemerintah terutama dari Badan Usaha Milik Negara (BUMN) yang memberikan kontribusi yang cukup besar terhadap tabungan pemerintah secara keseluruhan.

Pada umumnya peran tabungan pemerintah memang sangat kecil. Cara yang paling sering digunakan untuk memobilisasi tabungan pemerintah adalah melalui peningkatan rasio pengumpulan pajak terhadap GNP, reformasi struktur pajak, dan jika mungkin melalui peningkatan tingkat pajak yang telah ada. Menghentikan Utang Luar Negeri dengan Tabungan

Pemerintah Sudah seharusnya pemerintah mengurangi pinjaman luar negeri karena sekarang saatnya memikirkan kemandirian. Dalam arti kita harus mampu menggunakan dana-dana yang ada di masyarakat daripada harus berutang. Hanya saja ada dua masalah, yaitu dari mana dana dalam negeri dan bagaimana kalau dana dalam negeri tidak bisa menggantikan dana luar negeri.

b. Tabungan Swasta Domestik Di banyak negara, tabungan swasta memberikan peran besar dalam menunjang pembentukan modal. Pengumpulan tabungan swasta domestik berhasil dengan baik jika masyarakat berhasil mengurangi tingkat konsumsinya. Tabungan swasta terdiri atas dua komponen yaitu tabungan rumah tangga dan tabungan perusahaan.

1) Tabungan Rumah Tangga

Tabungan rumah tangga meliputi tabungan yang berasal dari upah, hasil usaha-usaha pribadi, partnership dan bentuk-bentuk bisnis nonkorporasi. Tabungan rumah tangga akan sangat rendah jika tingkat pendapatan tetapi kecenderungan berkonsumsi tetap tinggi. Sedikitnya tabungan yang dimiliki masyarakat karena tingginya tingkat belanja rumah tangga untuk konsumsi kebutuhan primer biaya anak sekolah, dan kebutuha

2) Tabungan Perusahaan Tabungan perusahaan merupakan laba yang ditahan oleh perusahaan-perusahaan setelah pendapatan bersih perusahaan dikurangi dividen yang dibayarkan kepada para pemegang saham. Jika perusahaan-perusahaan di suatu negara masih banyak yangberskala kecil, maka tingkat tabungannya juga relatif lebih rendah. Perusahaan yang kecil juga mengalami kesulitan menyisihka banyak tabungan. Selain itu, perusahaan sulit menabung karena tingginya jumlah dana untuk membayar utang.

c. Tabungan Asing/Luar Negeri Tabungan asing/luar negeri berasal dari dua sumber, yaitu tabungan pemerintah asing atau bantuan luar negeri dan tabungan 
swasta asing yang terdiri atas investasi asing terutama oleh perusahaan multinasional dan pinjaman komersial eksternal. Komponen-komponen tabungan ini penting untuk mengetahui aliran modal keluar atau investasi yang menggambarkan penggunaa tabungan. Jumlah tabungan yang tersedia di suatu negara secara sederhana merupakan jumlah tabungan pemerintah, tabungan domestik, dan tabungan asing

\section{METODE PELAKSANAAN}

Dalam melaksanakan kegiatan PKM ini digunakan beberapa metode yaitu:

1. Metode Ceramah/Presentasi,

Metode ceramah/ presentasi

dipilih untuk memberikan penjelasan mengenai:

a. Memberikan pengetahuan terkait dengan memanajemen keuangan keluarga yang baik dan benar ditengah pandemic covid-19

b. Memberikan pengetahuan terkait dengan cara meminimalisir pengeluaragan keuangan keluarga secara efektif ditengah pandemic covid-19

c. Memberikan pengetahuan terkait dengan cara menumbuhkan minat menabung bagi Ibu PKK ditengah pandemic covid-19

2. Metode Tanya Jawab

Metode Tanya jawab sangat penting bagi para peserta. Metode ini memungkinkan para ibu PKK menggali pengetahuan sebanyakbanyaknya tentang Pentingnya Manajemen Keuangan Keluarga Pada Ibu PKK Kelurahan Pondok Benda Guna Meminimalisir Pengeluaran Dan Animo Menabung Ditengah Pandemi Covid-19.

3. Sharing Session. Tentang Pentingnya Manajemen Keuangan
Keluarga Pada Ibu Pkk Kelurahan Pondok Benda Guna Meminimalisir Pengeluaran Dan Animo Menabung Ditengah Pandemi Covid-19. Sharing session ini diberikan kepada para peserta guna mendorong membimbing Ibu PKK.

\section{PEMBAHASAN}

Pondok Benda adalah sebuah Kelurahan, Terletak di Kecamatan Pamulang, Kotamadya Tangerang Selatan, Propinsi Banten - Indonesia. Yang memiliki jumlah total penduduk sebanyak 45.679, dan memiliki jumlah RW sebanyak 24 serta 146 RT.

Berikut adalah hasil dari PKM Prodi Manajemen Universitas Pamulang, sebagai berikut:

1. Manajemen Keuangan yang baik dan benar ditengah pandemic covid-19 pada Ibu PKK pada Kelurahan Pondok Benda.

Untuk dapat menjalankan roda kehidupan keluarga secara bijak, pentingnya bagi sebuah keluarga untuk menjalankan tiga langkah berikut ini, (Iswandi dan Saiful Amiq, 2013):

\section{Mengidentifikasi dan} Menetapkan Prioritas Keuangan.

Menentukan prioritas keuangan secara spesifik merupakan langkah awal dalam sebuah menajemen keuangan keluarga. Menentukan prioritas keuangan keluarga yang sesuai dengan keinginan masingmasing anggota keluarga membutuhkan perbincangan yang dalam. Dibutuhkan keterbukaan serta kesepakatan anggota keluarga khususnya ibu dan bapak yang akan membawa atau memimpin keluarga.

2. Memikirkan dan Mengembangkan Sebuah Rencana Pencapaian. Saat 
seseorang telah menetapkan prioritas tujuan keuangan keluarga, maka ia memerlukan sebuah stratetgi atau perencanaan yang harus dilakukan agar prioritas tersebut tercapai. Karena kondisi dan situasi keuangan setiap keluarga berbeda, maka berikut ini akan di uraikan gambaran umum seputar hal-hal yang sebaikanya dialakukan dalam melihat strategi atau perencanaan keuangan keluarga.

a) Diperlukan sebuah anggaran belanja.

Penganggaran merupakan salah satu bagian terpenting dalam mengelola keuangan keluarga. Dengan anggaran belanja akan membantu untuk mengenali kemungkinan masalahmasalah yang akan timbul dalam pola pengeluaran. Dengan begitu, dapat dicari cara-cara mengatasi masalah tersebut.

b) Miliki sebuah perencanaan menabung. Selama ini kita mengenal pola menabung hanya dari sisa belanja bulanan. Itu merupakan cara yang sangat kuno dan tidak efektif. Sekarang alokasi menabung itu harus masuk sebagai pengeluaran rutin yang harus didahulukan. Karena kalau menunggu sisa, seringkali tidak ada sisanya di akhir bulan.

c) Bijak mengambil hutang. Paling tidak ada tiga (3) petunjuk dasar yang di butuhkan dalam mempertimbangkan pinjaman yang akan di ambil. Pertama, Jangan pernah meminjam lebih besar dari kemampuan keuangan. Kedua, Jangan pernah meminjam untuk kebutuhan barang-barang mewah, seperti mobil mewah, perhiasan, bila dengan hal itu tidak dapat meminjam untuk kebutuhan keluarga seperti, pinjaman kredit rumah atau pinjaman pribadi untuk biaya sekolah anak. Ketiga, harus di Pastikan bahwa masih menyisakan kapasitas dalam meminjam untuk kebutuhankebutuhan yang tidak terduga.

d) Alokasikan dana untuk mencapai prioritas tujuan keuangan yang dimiliki. Setiap keluarga pasti memiliki tujuan yang berbeda. Berdasarkan prioirtas tujuan tersebut alokasikan dana untuk menacapinya. Contoh dari tujuan keuangan keluarga seperti menyiapkan dnaa pendidikan anak, masa pensiun dan lain-lain.

3. Mengembangkan Prosedur Pelaksanaan Perencanaan

Bekerja sebagai sebuah tim (keluarga) dalam menajeman keuangan keluarga dapat mengurangi atau menangkis sumber permasalahan dan kesalahpahaman. Walaupun penetapan tujuan serta pengembangan perencanaan telah dilakukan, kita harus memutuskan 
siapa yang melaksanakan rencana atau apa yang menjadi prosedur pelaksaan perencanaan yang telah disepakati bersama.

Dalam sebuah keluarga mungkin antara suami-istri bisa membagi tanggung jawab. Misalkan keduanya bekerja (suami dan istri), dapat dibagi siapa yang bertanggung jawab terhadap tagihan-tagihan yang ada. Misalkan, istri lebih memprioritaskan untuk memenuhi anggaran belanja bulanan. Sedangkan suami bertanggung jawab untuk biaya listrik, telp, tabungan pendidikan, pensiun dan lain-lain.

Bila hanya suami atau istri yang bekerja, maka suami-istri tersebut haruslah membicarakan tugas serta tanggung jawab masingmasing. Mungkin sebagai suami karena bekerja yang berusaha memenuhi semua kebutuhan keluarga. Sedangkan istri yang tinggal di rumah bertanggung jawab dalam hal rumah tangga, mulai dari persoalan belanja regular bulanan sampai alokasi tabungan (dari pendapatan suami) untuk berbagai macam tujuan keuangan keluarga yang dimiliki. Dalam hal ini istri harusnya seperti manejer dalam sebuah perusahaan.

$$
\text { Dengan membagi }
$$

tanggung jawab bersama, suami tidak lagi merasa lebih dibandingkan istri. Karena kedua individu dalam keluarga tersebut memiliki tanggung jawab masingmasing. Untuk itulah keterbukaan dan diskusi mengenai keuangan menjadi sangat dibutuhkan.Yang terpenting dalam hal ini adalah kesepakatan bersama. Maka prosedur pelaksanaan yang ditentukan adalah yang memang sesuai dengan kondisi keluarga.

2. Cara meminimalisir pengeluaran keuangan keluarga secara efektif ditengah pandemic Covid-19 pada Ibu PKK Pondok Benda.

Cara meminimalisir pengeluaran, anatara lain:

a. Tinjau anggaran dan pengeluaran harian Anda. Meskipun Anda tetap terisolasi, ini adalah waktu yang tepat untuk merenungkan pengeluaran Anda saat ini dan memahami perbedaan antara apa yang kita butuhkan dan apa yang kita inginkan. Sangat penting bagi kita untuk meninjau anggaran dan pengeluaran harian kita setiap hari dan memprioritaskan kebutuhan kita daripada keinginan kita.

b. Kurangi pengeluaran yang tidak perlu. Sebagaimana dibahas, seseorang harus belajar membedakan antara 'kebutuhan' dan 'keinginan'. Selama krisis ekonomi, kita tidak bisa gegabah dan menikmati pengeluaran irasional untuk barang-barang yang tidak penting. Hanya ketika Anda mengurangi pengeluaran yang tidak perlu, Anda dapat meningkatkan kemampuan menabung Anda, yang akan menyelamatkan Anda pada saat dibutuhkan.

c. Lakukan transaksi Anda secara digital. Hal yang bijaksana untuk mengubah mode pembayaran Anda dari offline ke online, ketika Anda sedang terkunci. Virus corona telah mempengaruhi orang di seluruh dunia dan oleh karena itu setiap 
Loyalitas Kreativitas
Aldi Masyarakat Kreatif
P-ISSN 2722-2101, E-ISSN 2722-4201

Program Studi Ekonomi Manajemen Universitas Pamulang

Jurnal LOKABMAS Kreatif Vol. 01, No. 03, Hal. 112-123

Email:jurnalkreatif.manajemen@gmail.com orang diharuskan untuk tinggal di rumah dan mempraktikkan isolasi diri. Demikian pula, bank dan lembaga keuangan lainnya juga telah ditutup untuk menghindari kontak antara orang-orang. Dalam hal itu, Jika Anda melayani pinjaman seperti pinjaman rumah, pinjaman pribadi atau pinjaman mobil dan perlu membayar EMI Anda, Anda mungkin ingin beralih ke pembayaran digital. Meskipun Anda mungkin tidak memiliki akses ke bank, pembayaran EMI Anda dapat tertunda yang dapat menyebabkan biaya keterlambatan atau default pinjaman.

3. Cara menumbuhkan minat menabung bagi Ibu PKK ditengah pandemic Covid-19.

Berikut adalah cara menumbuhkan minat menabung (Yupita, 2020) sebagai berikut:

4. Catat pengeluaran. Tips yang pertama untuk mulai menabung adalah dengan mencari tahu berapa banyak uang yang akan kamu belanjakan nantinya.Selalu pantau pengeluaran dengan membuat catatan setiap kamu menerima dan mengeluarkan uang agar kamu mengetahui pengeluaranmu setiap harinya. Jangan lupa sisihkan uangmu un tuk ditabung.

5. Anggaran untuk berhemat. Setelah kamu mencatat kebutuhanmu selama satu bulan, kamu dapat mulai mengatur pengeluaran yang tercatat dalam anggaran yang dapat diterapkan. Anggaran harus menjelaskan bagaimana pengeluaran yang kamu pakai sesuai dengan penghasilanmu, sehingga kamu dapat membatasi pengeluaran jika berlebih.

6. Memangkas pengeluaran. Jika pengeluaranmu terlalu tinggi dan tidak ada uang yag bisa ditabung, maka sudah saatnya kamu untuk mengurangi pengeluaranmu. Seleksilah hal-hal yang tidak penting. Cara sederhana misalnya dengan tidak mudah tergoda dengan keinginanmu dan utamakan apa yang menjadi kebutuhan terlebih dahulu.

7. Tetapkan tujuan penghematan. Tips lain menghemat uang adalah dengan menetapkan tujuan. Mulailah dengan memikirkan apa yang ingin kamu 'selamatkan', misalnya kamu mau menikah atau merencanakan liburan. Kemudian mencari tau berapa jumlah uang yang kamu butuhkan dan membuat perkiraan berapa lama kamu bisa mengumpulkannya.

8. Tentukan prioritas. Setelah pengeluaran dan penghasilan, sasaran kamu cenderung memiliki dampak terbesar pada bagaimana kamu mengalokasikan tabungan kamu. Pastikan untuk mengingat tujuan jangka panjang agar kamu benar-benar menabung untuk prioritas jangka panjangmu.

\section{KESIMPULAN DAN SARAN \\ Kesimpulan}

Adapun kesimpulan dari PKM ini adalah:

1. Membantu Perencanaan dan Pemenuhan KebutuhanKebutuhan hidup keluarga tentu memiliki komponen yang begitu beragam. Hal ini berlaku baik untuk kebutuhan tetap yang bersifat harian atau rutin, maupun kebutuhan jangka panjang. Banyak keluarga yang hanya berfokus pada pemenuhan kebutuhan rutin misalnya seperti pembayaran biaya sewa tempat tinggal atau cicilan rumah, hingga belanja bulanan. Tanpa disadari, pola pengaturan keuangan seperti ini bisa jadi kurang efektif dan tidak memiliki dimensi keberlanjutan. Namun dengan manajemen keuangan yang baik, alokasi income dapat mulai mengarah 


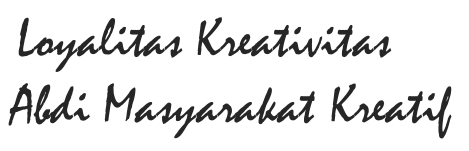

P-ISSN 2722-2101, E-ISSN 2722-4201

Program Studi Ekonomi Manajemen Universitas Pamulang

Jurnal LOKABMAS Kreatif Vol. 01, No. 03, Hal. 112-123

Email:jurnalkreatif.manajemen@gmail.com pada kebutuhan di masa yang akan datang. Misalnya menyiapkan tabungan untuk membayar uang pangkal kuliah anak. Jangan sampai ketika waktunya tiba, orang tua tidak memiliki kesiapan untuk menjangkau biayanya.

2. Meningkatkan Cash Flow Keluarga. Keluarga dengan pengelolaan keuangan yang baik mampu memonitor secara detail setiap akun rekening yang dimiliki. Hal ini termasuk mengidentifikasi berbagai sumber pemasukan tambahan berikut pos pengeluaran. Kebiasaan baik ini tidak hanya membuat pembelanjaan menjadi lebih terkendali, namun juga bisa mendorong kreativitas. Orang tua bisa mulai memikirkan peluang sumber pemasukan baru tanpa mengganggu sumber pemasukan utama. Cash flow keluarga akan semakin baik dengan meningkatnya jumlah pemasukan. Cash flow yang meningkat ini nantinya juga mampu mendorong keluarga untuk mulai berinvestasi ataupun meningkatkan nilai investasi.

3. Membantu Keluarga Saat Membuat Keputusan Finansial Besar.

Dalam perjalanannya, keluarga mungkin berhadapan dengan berbagai keputusan finansial yang besar. Keputusan ini misalnya seperti pembelian rumah ataupun menyekolahkan anak hingga ke luar negeri. Tentu ini semua membutuhkan kesiapan finansial yang matang dengan mempertimbangkan berbagai risikonya. Tanpa adanya manajemen keuangan yang efektif dan efisien, sulit membayangkan keputusan finansial seperti ini akan dapat terealisasi.

4. Mendorong Perilaku Hemat di Keluarga. Salah urus finansial di dalam keluarga salah satunya berawal dari perilaku ataupun kebiasaan boros misalnya belanja barang karena alasan diskon. Di satu sisi, keluarga yang menjadikan manajemen keuangan sebagai prioritas, akan cenderung lebih menghargai pentingnya berhemat dan menyimpan uang untuk hari depan. Kebiasaan hemat di keluarga tidak hanya berpengaruh pada orang dewasa, namun juga membantu anak-anak untuk mulai menyukai aktivitas menabung. Prinsip manajemen keuangan berupa sikap hidup hemat ini pada akhirnya akan menghindarkan keluarga dari "accidental overspending". Tentu Parent Pinters ingin segala pembelanjaan tepat sasaran dan memiliki dampak positif pada tujuan jangka panjang keluarga.

5. Membuat Keluarga Merasa Lebih Aman. Keluarga yang memiliki perencanaan serta pengelolaan keuangan yang baik, akan merasa lebih aman dalam menjalani hari-harinya. Tidak hanya itu, keluarga juga lebih siap ketika harus menghadapi masamasa sulit. Terkadang pelemahan ekonomi terjadi hingga pemasukan pun tidak selalu stabil. Bahkan bayangbayang pemutusan hubungan kerja bisa saja menghantui. Atau bisa saja hal yang tidak diinginkan lainnya terjadi, misalnya ketika salah satu pencari nafkah harus berhenti bekerja sementara waktu karena masalah kesehatan. Keluarga yang sudah melek akan pentingnya manfaat manajemen keuangan, akan lebih siap menghadapi masa-masa ini. Biasanya mereka sudah memiliki dana darurat yang dikumpulkan jauh-jauh hari dan siap digunakan pada waktu yang tepat.

6. Mendorong Keluarga Lebih Cerdas dalam Mengelola Pinjaman.

Manajemen keuangan keluarga ternyata juga mempengaruhi perilaku 
Loyalitas Kreativitas
Aldi Masyarakat Kreatil
P-ISSN 2722-2101, E-ISSN 2722-4201

Program Studi Ekonomi Manajemen Universitas Pamulang Jurnal LOKABMAS Kreatif Vol. 01, No. 03, Hal. 112-123

Email:jurnalkreatif.manajemen@gmail.com orang tua dalam mengelola pinjaman. Orang tua yang cerdas akan memanfaatkan pinjaman untuk hal nonkonsumtif yang tidak akan pernah berkurang nilainya. Misalnya seperti pinjaman untuk membayar biaya kuliah ataupun kursus. Tentu sangat disayangkan jika orang tua mengajukan pinjaman hanya untuk belanja hal yang nilainya akan surut seperti alat rumah tangga dan pakaian. Sementara dengan pinjaman pendidikan, anak dapat mengakses ilmu dan keterampilan untuk menyiapkan masa depannya. Tidak hanya itu, contoh manajemen keuangan keluarga yang cerdas juga dapat terlihat ketika orang tua disiplin dalam membayar cicilan pinjaman. Tentu hal ini akan meningkatkan skor kredit orang tua dan menjadikannya sebagai peminjam berisiko rendah. Tidak jarang, orang tua yang memiliki riwayat peminjaman baik, akan dapat mengakses pinjaman dengan tenor dan bunga yang lebih menarik.

\section{Saran}

Berdasarkan hasil pembahasan diatas, maka tim PKM menyarankan sebagai berikut:

1. Ibu PKK lebih selektif dalam memilih/membeli kebutuhan (primer, sekunder, dan tersier)

2. Ibu PKK Kelurahan Pondok Benda Lebih bijak dalam menentukan bank yang akan digunakan berdasarkan kebutuhan di masa mendatang.

3. Ibu PKK dapat terus meningkatkan pengetahuan keuangan agar dapat memanfaatkan tabungan yang dimilki di masa mendatang.

\section{DAFTAR PUSTAKA}

Hasibuan, Malayu S.P. (2012). Manajemen
Sumber Daya Manusia. Jakarta: PT Bumi Aksara.

Iswandi dan Saiful Amiq, 2013, “ Manajemen Keuangan Keluarga I" Artikel Onlinine

https://juraganmakalah.blogspot.com/ 2013/03/manajemen-keuangankeluarga-i.html (Diakses Hari Selasa 6 Oktober 2020)

Kasmir. (2017). Analisis Laporan Keuangan. Edisi ke-8, Cetakan ke-8. Jakarta : PT. RajaGrafindo Persada.

Kabae, Zaenuddin. 2016. "Pengertian Konsumsi, Tabungan Dan Investasi”. Ekonomi akuntansi id. https://www.bahanbelajar.com/2016/0 7/pengertian-konsumsi-tabungandan.html. (diakses Hari Rabu, 4 November 2020).

Oktrima, B., Tumanngor, M., Jati, W., Wartono, T. \& Sari, A. R. (2020) PENGELOLAAN KEUANGAN KELUARGA PADA KELOMPOK PENGAJIAN IBU-IBU SEKELURAHAN PAMULANG BARAT TANGERANG SELATAN. Jurnal ABDIMAS Tri Dharma Manajemen, 1(2).

Pasaribu, V. L. D., Susanti, F., \& Hartuti, E. T. K. (2019). Memotivasi Siswa dan Siswi SMK Letris Indonesia di Dalam Menentukan Pilihan Untuk Melanjutkan Pendidikan Atau Bekerja Setelah Lulus Sekolah. Jurnal Pengabdian Dharma Laksana, 1(2), 161-172.

Pasaribu, V. L. D., Elburdah, R. P., Sudarso, E., \& Fauziah, G. (2020). PENGGUNAAN MANAJEMEN WAKTU TERHADAP PENINGKATAN PRESTASI BELAJAR DI SMP ARAISIYAH. Jurnal ABDIMAS Tri Dharma Manajemen, 1(1).

Pasaribu, V. L. D., Agrasadya, A., Shabrina, N., \& Krisnaldy, K. (2020). MENJADI ENTERPRENEUR MUDA YANG MEMILIKI JIWA LEADERSHIP 
Loyalitas Kreativitas

Aldi Masyarakat Kreatif
P-ISSN 2722-2101, E-ISSN 2722-4201

Program Studi Ekonomi Manajemen Universitas Pamulang Jurnal LOKABMAS Kreatif Vol. 01, No. 03, Hal. 112-123 Email:jurnalkreatif.manajemen@gmail.com
UNTUK MENGHADAPI MASA

DEPAN. Abdi Laksana, 1(1).

Pasaribu, V. L. D., Sulaiman, S., Sutiman, S., Thaharudin, T., \& Purnomo, B. Y. (2020). PENGENALAN LETAK POSYANDU TERDEKAT

DIKELURAHAN PISANGAN DENGAN MANAJEMEN PEMASARAN

REVOLUSI 4.0 UNTUK

MENINGKATKAN PENGETAHUAN MASYARAKAT LETAK DAN FUNGSI POSYANDU TERDEKAT PADA KELURAHAN PISANGAN. DEDIKASI PKM, l(1), 105-110.

Priadi, A., Pasaribu, V. L. D., Virby, S., Sairin, S., \& Wardani, W. G. (2020). PENGUATAN EKONOMI KREATIF BERBASIS SUMBER DAYA DESA DIKELURAHAN REMPOA. Abdi Laksana, 1(3), 356358

Weston, J. Feed dan Thomas E. Copeland. (2010). Manajemen Keuangan. Jakarta: Binarupa Aksara.

Yupita, Helena. 2020. "Sulit Menumbuhkan Niat Menabung, Begini Tipsnya" https://www.liputan6.com/bisnis/read/ 4157776/sulit-menumbuhkan-niatmenabung-begini-tipsnya. (diakses Hari Rabu, 4 November 2020)

https://pintek.id/blog/manajemenkeuangan/

\section{DOKUMENTASI FOTO KEGIATAN}

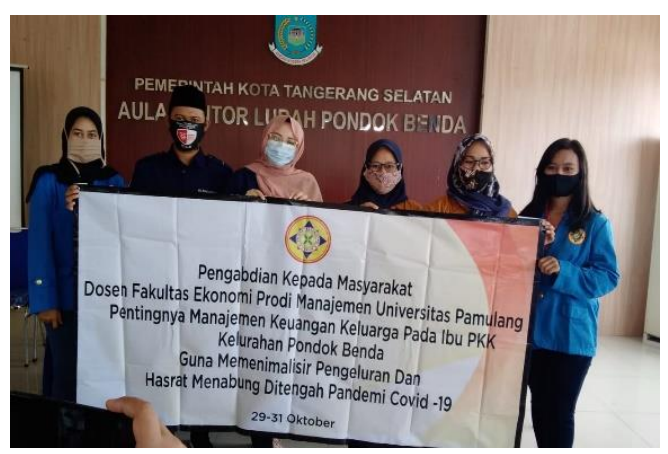

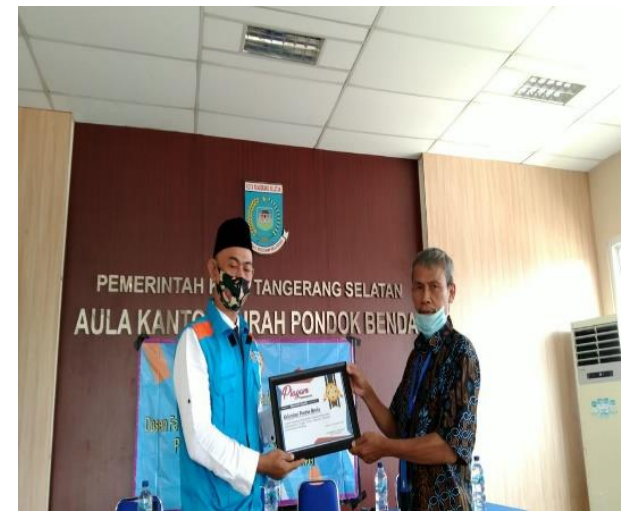
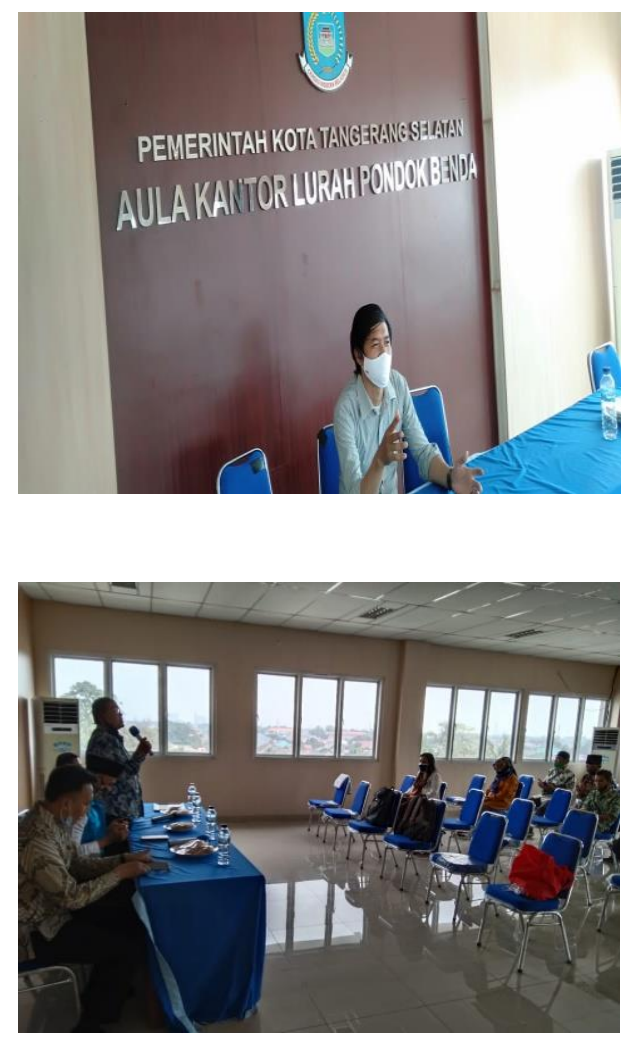